\title{
ATEÍSMO NO BRASIL: DA INVISIBILIDADE À CRENÇA FUNDAMENTALISTA
}

\author{
PAUla MONTERO \\ EDUARDO DULLO ${ }^{1}$
}

\begin{abstract}
RESUMO
Apesar do aumento significativo do número de brasileiros que se declaram sem religião, de acordo com o Censo de 2010, o ateísmo como doutrina política permanece praticamente invisível como fenômeno social e como objeto de pesquisa acadêmica no Brasil. A partir da problemática mais ampla da discussão sobre a laicidade e a formação de uma sociedade secular, este artigo propõe descrever a tentativa de veiculação de uma campanha ateísta nos transportes públicos (por parte da Associação de Ateus e Agnósticos - ATEA) e analisar as razões para o fracasso da campanha. Considerando as reações à campanha e a acusação de "fundamentalismo" direcionada à ATEA, argumentamos que o ateísmo é reinterpretado socialmente no Brasil como uma escolha interna ao campo das religiões.
\end{abstract}

PALAVRAS-CHAVE: ateísmo; campanha ateísta; $A T E A$; religiões;

laicidade; Brasil.

\section{ABSTRACT}

According to the 2010 census the number of Brazilians that consider themselves as non-religious has increased substantially. Nevertheless, atheism as a political doctrine and as a subject of research remains an almost invisible phenomenon in Brazil. As part of a larger ongoing research on the formation of a secular society and on the social limits of laicity in Brazil this text presents a description of the attempt of the Association of Brazilian Atheists and Agnosticists (ATEA) to launch a campaign in the public transport system and analyse the reasons of its failure. After the reactions to the ATEA campaign and the accusations of fundamentalism we claim that the atheism is socially interpreted as a personal choice within the scope of religion.

KEYWORDS: atheism; atheist campaign; ATEA; religions; laicity; Brazil.

[1] Este artigo não teria sido possível sem a preciosa colaboração de Rafael Quintanilha, que nos ajudou a reunir os dados que fundamentam esta reflexão. Também agradecemos o apoio da Fundação de Amparo a Pesquisa do Estado de São Paulo (FAPESP) ao grupo de pesquisa "Religiões e Controvérsias Públicas", que vem desenvolvendo um trabalho sobre a laicidade no Brasil, bem como a bolsa de pós-doutorado processo 2013/16433-3.

\section{INTRODUÇÃo}

O Brasil é reconhecidamente um país de formação histórica católica. Apesar das rupturas institucionais com a Igreja e dos conflitos políticos que daí resultaram, o processo de secularização do Estado que acompanhou a institucionalização das estruturas políticas republicanas não se caracterizou, no entanto, nem pelo anticlericalismo, nem como uma luta contra a religião. Além disso, as disputas de parte das elites brasileiras contra a Igreja Católica não foram sinôni- 
mo de uma defesa do ateísmo. Muitos dos mais importantes próceres republicanos, tais como Joaquim Nabuco e Rui Barbosa, propunham para o Brasil um catolicismo "mais racional" e "livre de superstições" que, para os críticos liberais, caracterizavam o catolicismo "fetichista" das camadas populares ${ }^{2}$.

Essas peculiaridades do processo político que levaram à instauração de um regime institucional-jurídico republicano nos permitem compreender por que não se enraizou na alma brasileira uma cultura cívica laica, ou, dito de outro modo, por que a formação de uma sociedade secular foi caudatária, em grande parte, do esforço de intelectuais e pensadores católicos para erradicar a religiosidade mágico-devocional tão arraigada na experiência popular. Com efeito, como procuramos demonstrar em trabalhos recentes 3 , a formação da sociedade civil e da esfera pública como entidades separadas da esfera política deveram, em grande parte, sua configuração e gramática ao trabalho de mobilização política e mediação pedagógica de lideranças católicas leigas e eclesiásticas no sentido de promover, ao longo do século XX, a "emancipação libertadora" das camadas mais pobres. O "povo brasileiro", contraparte do Estado soberano em sua forma republicana, foi, pois, reiteradamente narrado em termos de alegorias cristãs que descreviam sua "salvação" a partir da figura do "pobre" e da possibilidade de superação de sua "opressão" por meio de "pedagogias da consciência" capazes de desarraigar as formas populares de crença.

Se voltarmos nossa atenção para os modos como as tecnologias censitárias do Estado vão transformando a imaginação política da sociedade, pode-se notar que a "religião" do brasileiro foi parte do projeto de construção nacional ainda no Império, quando, em 1872, classificou-se a população em católicos e acatólicos. Desde o primeiro censo, de 1940, e em todos os censos subsequentes, o levantamento incluiu uma questão sobre o perfil religioso da população4. Nas quatro décadas que se seguiram o catolicismo representou a quase totalidade da população (acima de 90\%); em contrapartida, no mesmo período, os que se declaravam "sem religião" aparecem estatisticamente como insignificantes (menos de 1\%). Pode-se considerar a década de 1980 como o turning point de uma importante mutação. Pela primeira vez o catolicismo cai abaixo da marca dos $90 \%$ e as estatísticas passam a desenhar uma linha de queda acelerada, que em 2010 chega ao seu ponto mais baixo $(64,6 \%)$. Ao lado desse decréscimo, os levantamentos começaram a indicar um rápido aumento dos protestantes, que, em cinco décadas, passaram de 5,2\% da população para 22,2\%.

O movimento de desnaturalização do catolicismo como componente da nacionalidade é bastante recente e traz como consequência a percepção de que ele representa não um modo de ser, mas, apenas, uma "escolha religiosa" entre outras possíveis. Ao jogar luz sobre o declínio
[2] Souza, Ricardo Luiz de. "O anticlericalismo na cultura brasileira". Revista de Ciências Humanas, Florianópolis, $\mathrm{n}^{\circ} 37,2005$, p. 186.

[3] Montero, Paula. "O campo religioso, secularismo e a esfera pública no Brasil". Boletim CEDES. PUC-RJ, 2011; Dullo, Eduardo. A produção de subjetividades democráticas e a formação do secular no Brasil a partir da pedagogia de Paulo Freire. Tese de doutorado (Antropologia Social). Rio de Janeiro: Museu Nacional/ UFRJ, 2013.

\footnotetext{
[4] A questão sobre a religião foi sempre aberta, com exceção do censo de 1970, único a adotar uma questão fechada com apenas seis categorias. Em todos aparece a categoria "sem religião". O censo de 1960 introduz procedimento amostral deslocando a questão sobre religião para o questionário da amostra. Ver Decol, René D. "Mudanças religiosas no Brasil: uma visão demográfica". Revista Brasileira de Estudos Populacionais, n ${ }^{\circ} 16$, vol. $1 / 2,1999$.
} 
[5] No campo político o pluralismo pressupõe que uma das características definidoras de um sistema democrático depende da existência de vários partidos com igual direito ao exercício do poder. Decorre desse sistema a necessidade de criar procedimentos claramente definidos para garantir a coexistência de várias opiniões e ideias divergentes.

[6] Os censos sempre apontaram, desde o século XIX, a presença reduzida de outras religiões não cristãs. Por que elas nunca foram percebidas como "minoritárias" e nunca atuaram como tal é um fato ainda pouco estudado. $O$ conceito político de minoria é muito recente. $O$ Pacto Internacional dos Direitos Civis e Políticos, de 1966, proposto pela ONU foi o primeiro instrumento normativo internacional a tratar do tema. $\mathrm{O}$ Brasil assinou esse documento somente em 1992. Embora a Constituição de 1988 não faça menção direta a "minorias", garantindo apenas direitos "culturais", objetivamente são tratadas como minorias somente as populações indígenas e, mais recentemente (1993), as minorias étnicas (quilombos), que passam a ter no Ministério Público Federal um órgão de defesa de seus direitos e interesses. Ver Monteiro, Adriana C.; Barreto, Gley P.; Oliveira, Isabela L. de;Antebi, Smadar.Minorias étnicas, linguísticas e religiosas, s. 1., 2010: DHnet-Direitos Humanos. dhnet.org.br/dados/cursos/dh/br/pb/dhparaiba/5/minorias. html (consultado 14/4/2014).

[7] Montero, Paula e Almeida, Ronaldo. "Trânsito religioso no Brasil". Revista São Paulo em Perspectiva, São Paulo, v. 15, n 3 , 2001, pp. 17-35. do catolicismo e sobre o rápido crescimento evangélico, a quantificação censitária permite formular, pela primeira vez, a diversidade religiosa em termos da categoria política de "pluralismo"s. Permite ainda definir o catolicismo como religião "majoritária" e acionar a categoria de "minorias religiosas" 6 como alvo potencial de uma política de proteção e/ou controle estatal.

Além do crescimento dos cristãos não católicos, a categoria dos "sem religião" aparece de maneira mais perceptível no censo de 1980 quando, pela primeira vez, ela cruza a barreira do $1 \%$. Nas quatro décadas seguintes, acompanhando o crescimento dos que se declaram evangélicos, o número dos que se declaram "sem religião" cresce gradualmente e chega a $8 \%$ da população em 2010 , bem acima do espectro das "alternativas religiosas" não cristãs, que alcança apenas $3 \%$ nessa data.

O mote do "pluralismo religioso" - inscrito na Constituição de 1988, que pôs fím ao período ditatorial — se desenha como pauta política para as décadas seguintes em um contexto marcado pelas seguintes características: a distribuição da diversidade religiosa é extremamente desigual (mais de $90 \%$ cristã); a ideia de "minoria" é assumida como bandeira política principalmente pelos evangélicos; no mesmo movimento em que a "religião" começa a ser percebida como objeto de opinião individual, "não professar religião alguma" se apresenta como a alternativa disponível no campo das "escolhas religiosas".

Ainda que esses números tenham desencadeado um amplo debate acadêmico em torno do "declínio da hegemonia católica", parte dele dedicado a explorar o fenômeno do "trânsito religioso"7 como explicação dos que não declaram uma filiação religiosa institucional, a posição dos "sem religião" ainda não foi discutida a partir dos que declaram não acreditar em Deus. Com efeito, pode-se observar uma significativa lacuna na literatura sobre o ateísmo no Brasil, o que, a nosso ver, reforça a percepção da sociedade brasileira como eminentemente religiosa. Para desvendar, em parte, a natureza desse silêncio em torno do ateísmo, nos propomos neste artigo a compreendê-lo a partir da análise de um caso específico: o da tentativa da Associação Brasileira de Ateus e Agnósticos (ATEA) de tornar visível sua posição emulando uma campanha inglesa em defesa do ateísmo. O fracasso dessa campanha no Brasil, devido à recusa de parte dos meios de divulgação em veicular as imagens $e$ as frases elaboradas pela ATEA, e o tipo de reação que suscitou nos levaram à conclusão de que o ateísmo, quando se posiciona publicamente contra a religião, é percebido como uma "crença individual" entre outras e, enquanto tal, é devolvido ao campo das disputas religiosas, seus militantes sendo percebidos socialmente como uma "minoria fundamentalista". 
Nesse contexto particular, em que os enunciados concebíveis na cena pública tais como "não professar religião alguma" estão formulados pelos atores em termos de uma "escolha religiosa", para não dizer cristã, torna-se relativamente fácil compreender por que a posição ateísta permanece invisível e, mais do que isso, publicamente indefensável até o presente. Segundo o fundador da ATEA, o engenheiro Daniel Sottomaior, um dos objetivos da instituição é dar mais visibilidade ao ateísmo e torná-lo uma categoria mais distintiva e melhor representada no conjunto dos que declaram não ter religião.

Ainda que em 2010 os recenseadores do censo tivessem tido o cuidado de não apresentar ao entrevistado um cardápio oficial de respostas possíveis, para Sottomaior, a formulação da pergunta "qual é a sua religião ou culto?" teria induzido o recenseado a uma escolha binária: ou bem ele especifica a sua religião ou bem declara não ter nenhuma. A possibilidade de uma terceira alternativa, como "sou ateu", não estaria ainda, segundo ele, presente no espírito dos respondentes. Citando uma pesquisa da Fundação Perseu Abramo de 2008/2009, a posição de Sottomaior é, ainda, que a afirmação de si como "ateu" enfrentaria forte preconceito por parte da população, sendo a minoria que mais sofre rejeição por parte da opinião pública ${ }^{8}$.

Em contraposição ao opróbrio que se projeta sobre os que se dizem ateus, "não ter religião" é uma forma de apresentação de si relativamente bem-aceita socialmente, ou considerada com menos escândalo do que declarar "não acreditar em Deus". Tentar compreender essa sutil distinção mereceria um estudo mais detalhado que não cabe no escopo deste artigo. De um modo geral, "não ter religião" é uma afirmação que remete, em parte, ao fato de alguém apresentar-se como católico sem ser "praticante". Esse fenômeno é bem conhecido dos estudiosos do catolicismo no Brasil9 que descreveram o catolicismo das elites como "social", isto é, algo herdado, involuntário, e o catolicismo "popular" como meramente devocionale frágil em suas relações com as instituições eclesiásticas. Mas remete, também, à dimensão sincrética do catolicismo e à maneira como ele acaba por tornar-se o quadro de referência para a constituição e o reconhecimento de novas religiões ${ }^{10}$. $\mathrm{O}$ modo como o catolicismo operou como matriz de referência para a configuração da diversidade religiosa brasileira em todo o seu espectro desde as religiões mais africanizadas até os esoterismos mais recentes da Nova Era ofereceu as condições necessárias para que as delimitações religiosas permanecessem sempre porosas, sem nitidez e as organizações religiosas, sempre flexíveis e versáteis.
[8] Pesquisa de 2008/2009 realizada pela Fundação Perseu Abramo sobre "diversidade sexual e homofobia no Brasil". A pesquisa, que tinha por objetivo medir a intolerância a homossexuais e transgêneros, acabou por revelar que, dentre os grupos pesquisados, aqueles que "não acreditam em Deus" são os que sofrem os mais altos índices de rejeição por parte da opinião pública.

[9] Entre outros, Azevedo, Thales de. "Catolicismo no Brasil?". Revista Vozes, $\mathrm{n}^{\circ}$ 2, fevereiro 1969 , e Oliveira, Pedro A.R de. "Religiosidade popular na América Latina". Revista Eclesiástica Brasileira, fasc. $126, \mathrm{n}^{\circ} 32,1972$.

[10] Sanchis, Pierre. "As tramas sincréticas da história". Revista Brasileira de Ciências Sociais, vol. 28,1995; Montero, Paula. "Secularização e espaço público: a reinvenção do pluralismo religioso no Brasil". Etnográfica, vol. $13, \mathrm{n}^{\circ} 1,2009$. 
[11] Montero e Almeida, 2001, op. cit.
Nesse contexto, a proclamada "diversidade religiosa" tanto estudada na literatura especializada resultou, em parte, de um laborioso trabalho teórico de modelagem das diferenças cosmológicas e de definição de recortes institucionais e rituais precisos que procurou tornar inteligível a propagação quase infinita de variantes de todo tipo. Mas o modelo teórico assim construído, talvez útil para pensar o arranjo e o repertório das diferenças e suas estruturas de pensamento, não correspondia à "lógica das práticas" no sentido que Pierre Bourdieu dá a essa expressão, ou ao modo como os indivíduos se movem nesse campo e como descrevem aquilo que fazem. Com efeito, em estudo de 2001 pudemos demonstrar que as pessoas transitam constantemente por diferentes casas de culto sem necessariamente associar essas passagens a uma narrativa de "mudança de religião" ou de "conversão" pessoal ${ }^{11}$. Ao contrário, essa amplitude e flexibilidade nas formas de apropriação das variações disponíveis e articuladas pela matriz católica tornou verossímil e aceitável que, até muito recentemente, os indivíduos recenseados se declarassem católicos. Em contrapartida, na medida em que o "pluralismo religioso" e as lutas políticas pela tolerância e pela liberdade religiosa que o acompanham se disseminam como leitura da diversidade, mais a "religião" se torna o equivalente de uma instituição religiosa e mais pessoas passam a se autodesignar como "sem religião". Essa distinção também vai sendo formulada no próprio campo religioso com o crescimento evangélico neopentecostal, que não se apresenta como uma "religião" ou "igreja", mas sim como uma "fé". Assim, embora esse tema merecesse um estudo mais detalhado, não erraríamos muito ao afirmar que a categoria censitária dos "sem religião" cresce sem implicar, necessariamente, o declínio da "crença em Deus" e de práticas não institucionalizadas de todo tipo que, por economia, os analistas ainda chamam de religiosas.

Esse contexto particular nos permite compreender por que "não ter religião" torna-se a formulação convencional mais verossímil e aceitável para expressar a inespecificidade das práticas "religiosas". Ao mesmo tempo, nos permite compreender por que, no intuito de especificar e dar visibilidade a sua posição, os ateístas desenvolvem suas campanhas no próprio campo das lutas religiosas. Embora se apresente como uma posição de combate ao teísmo e a toda forma de "religião", a mobilização pública da associação se organiza na chave política do "pluralismo religioso": por um lado, reivindicando liberdade de expressão e de crença, direito constitutivo da liberdade religiosa; por outro, parafraseando, em sua luta contra o "preconceito", os modos de defender as minorias religiosas por meio de slogans tomados de empréstimo do vocabulário político das lutas de minorias raciais e sexuais. 
A criação da ATEA, como uma organização formal, é bastante recente (2008), e a tentativa de emular a veiculação da bus campaign no Brasil foi a primeira proposta concreta de dar visibilidade pública à organização. Até então, as manifestações na esfera pública ficavam restritas aos membros que, individualmente, se manifestavam como cidadãos. Segundo o presidente da associação, Daniel Sottomaior, a campanha inglesa o fez compreender a importância de realizar algo similar no Brasil para combater o que ele descreve como o "arraigado preconceito antiateu". Segundo nota oficial da ATEA, o objetivo principal da campanha era lutar por um Estado verdadeiramente laico e pelo reconhecimento dos descrentes como cidadãos plenos.

Segundo Sottomaior, o preconceito contra os ateus deve ser comparado ao racismo contra os negros e aos casos de discriminação contra a comunidade LGBT. Tomando como referência a pesquisa da Fundação Perseu Abramo já mencionada acima, ele relaciona casos de pessoas que perderam o emprego ou não foram contratadas após se declararem ateias, casos em que relacionamentos amorosos e familiares se romperam e até mesmo casos de ameaças físicas que ele sofreu em razão de seus posicionamentos públicos. Para ele, a existência de preconceito contra os ateus fica comprovada quando se nota que ameaças e agressões contra os que dizem não acreditar em Deus não geram debate nem causam desconforto. Em suas palavras, "não há sensibilidade" para esses casos de discriminação.

A iniciativa da ATEA não resultou de colaboração ou apoio dos responsáveis pela veiculação da campanha nos demais países. Consistiu, na verdade, em um empreendimento inteiramente pessoal de seu presidente, e, por essa razão, Sottomaior julgou ter liberdade para conceber seus próprios slogans e imagens. Apesar de ter apreciado a iniciativa inglesa, sua percepção do conteúdo daquela campanha não foi das mais favoráveis: ele a considerou pouco agressiva e "muito aguada". Além disso, ficou insatisfeito com a reiteração de apenas uma mensagem e acreditou que a variação de imagens e slogans seria uma forma de comunicação mais impactante e eficiente. A campanha foi produzida por uma agência de publicidade contratada pela ATEA, e a escolha do conteúdo foi feita pelos membros da organização, principalmente os membros da diretoria, que propuseram diversas frases, submetidas a votação dos associados por meio de uma enquete no site da ATEA. Desse modo, podemos dizer que as frases escolhidas para a campanha no Brasil são resultado tanto das percepções dos diretores da ATEA quanto das preferências dos membros mais ativos e engajados na militância em prol do ateísmo. A partir desse processo foram definidas quatro imagens com 
[12] É difícil precisar quando essa expressão se popularizou como palavra de ordem. É certo, no entanto, que, talvez tendo como referência campanhas antidrogas, ela serve hoje para a maior parte das causas que têm grande aceitação pública: "Diga não às drogas", "Diga não ao preconceito", "Diga não à violência", "Diga não à corrupção" etc. são expressões que estão em todo lugar.
[13] http://www.atea.org.br/index. $\mathrm{php} /$ index.php?option=com_content $\&$ view $=$ article \&id $=222 \&$ Ite $\mathrm{mid}=118$. Consultado em 27/4/2014. os respectivos slogans (veja as imagens abaixo, nas páginas 11-14). Coube à empresa contratada iniciar os contatos com as companhias de ônibus de diversos estados do Brasil no intuito de veicular as mensagens em seus espaços pagos destinados a publicidade.

Foi grande a surpresa da ATEA quando, ao tomarem ciência do conteúdo da campanha, as empresas recusaram os contratos de publicidade oferecidos. As justificativas apresentadas pelas empresas de ônibus se basearam majoritariamente nas proibições legais vigentes na legislação específica dos estados. Diante da impossibilidade de seguir com o plano inicial, a solução encontrada foi exibir a campanha em outdoors. Por razões estratégicas e de custo decidiu-se colocar, ao longo de um mês, quatro outdoors no centro de Porto Alegre. Na análise a seguir, procuraremos explicitar os elementos que, na perspectiva de sua audiência, transformaram aquilo que se apresentava como uma "crítica ao preconceito" em uma "ofensa aos que creem".

\section{SLOGANS E IMAGENS}

Sob o mote geral "diga não ao preconceito contra ateus" frase recorrente no ativismo político brasileiro contemporâneo ${ }^{12}$ os idealizadores lançaram quatro diferentes slogans: "Somos todos ateus, com os deuses dos outros"; "A fé não dá respostas. Só impede perguntas"; "Se Deus existe, tudo é permitido"; "Religião não define caráter". É interessante notar que, nessa forma de conceber a campanha, as frases sozinhas não conseguem comunicar e não fazem muito sentido; é a relação das frases com as imagens escolhidas que confere contundência às mensagens e provoca desconforto na opinião pública. Mas, antes de passarmos à análise dessa conjunção, atenhamos rapidamente nossa reflexão aos efeitos retóricos pretendidos e obtidos nesses quatro slogans.

Tomadas em conjunto, podemos observar que, em sua composição, as frases desafiam a religião a partir de dois registros principais: o primeiro diz respeito ao problema da crença; o segundo, ao problema da moralidade.

A primeira frase, "Somos todos ateus, com os deuses dos outros", faz um movimento argumentativo bastante interessante: em sua primeira assertiva (separada por uma vírgula) generaliza o ateís mo como parte inerente à condição humana. Nesse movimento procura retirar o ateísmo de sua posição imaginária de anomalia ou aberração. No movimento seguinte generaliza a crença: somos todos crentes, mas acreditamos em coisas diferentes. $O$ efeito retórico dessa conjunção, que pretende, à primeira vista, "colocar o teísta no lugar do ateu para que aquele possa vê-lo como um igual"13, acaba, no entanto, promovendo também o deslocamento 
inverso: aloca o ateísmo no registro das crenças, ao qualificá-lo como uma variação possível no campo da diversidade religiosa. Afirmar que todos "compartilhamos a mesma descrença com relação aos deuses dos outros" não é o mesmo que não ter deus algum. Ao referir-se aos "deuses dos outros", a mensagem mantém latente a aceitação da existência de um deus próprio, e, desse modo, o efeito generalizador buscado acaba por adscrever o ateísmo a uma posição relativa no campo geral do teísmo.

A segunda frase, "A fé não dá respostas. Só impede perguntas", também está composta de duas assertivas contrastantes no que diz respeito à qualificação da fé. Como pano de fundo silenciado, a fé aparece aqui em confronto com a ciência. Tomando por base implícita do argumento um modelo normativo e simplificador de ciência (como capaz de fazer perguntas e oferecer respostas), a formulação retira peremptoriamente a religião do campo do conhecimento: ela não conhece porque não pergunta, apenas crê. Poderíamos sublinhar aqui o movimento artificioso dessa retórica contrastiva, uma vez que todo estudioso das religiões ressaltaria a infinitude de perguntas que as religiões fizeram e fazem, e mais, como muitas das perguntas que elas se colocaram acabaram por promover o espírito científico ele mesmo. Mas veremos adiante, no entanto, que a imagem da Bíblia nas mãos do prisioneiro requalifica a assertiva e delimita a ideia geral de crença na direção de uma forma particular de crer: aquela do fundamentalismo.

Se as duas primeiras se relacionam com o estatuto da crença, as outras duas frases relacionam a religião a suas funções de controle social e produção de moralidades. A primeira, "Se Deus existe, tudo é permitido", remete, invertendo-a, à proposição bem conhecida de Dostoiévski na obra Os irmãos Karamázov, de 1879. Para Dostoiévski a moralidade natural que nos obriga a amar nosso semelhante estaria fundada na crença em Deus e na imortalidade; para os que não creem, a lei moral da natureza seria o egoísmo e até mesmo o crime. Segundo a ATEA, essa frase é recorrentemente utilizada em tom acusatório contra os ateus ${ }^{14}$. Ao evocá-la nesse slogan, a referência não tem por objetivo, segundo eles, fazer uma crítica à religião, mas sim aos sistemas éticos que elas mobilizam. No entanto, como veremos adiante, a imagem anexada à sentença também aqui lhe redireciona o sentido tornando-a mais radical.É de se notar ainda, permanecendo no plano da linguagem escrita, que a frase promove um deslocamento do plano da crença na qual se situa a formulação de Dostoiévski (se não acreditamos em Deus, nem na imortalidade) para o plano da falsificação da ideia da existência de Deus (se Deus não existe). Além disso, ao fazê-lo, volta-se para a falsificação da moralidade com Deus, procurando disputar, pelo escândalo, a posição hegemônica da religião na definição do Bem.
[14] Ver https://atea.org.br/index. php/etica.Consultadoem 26/4/2014. 
Finalmente, a última frase, "Religião não define caráter", coloca o problema da conduta moral. Contrariamente às anteriores, essaé a única proposição que não joga com antinomias, mas faz uma afirmação mais categórica. Dita desse modo genérico, ela poderia ser aceita sem grande controvérsia; mas causa escândalo pelas imagens escolhidas para acompanhá-la. Restringindo-nos ao seu aspecto mais conceitual, merece destaque a adoção do uso comum da ideia de "caráter" que reduz as várias dimensões da personalidade a seus traços morais. Se, em seu sentido mais estrito, todo indivíduo é dotado dessas disposições congênitas, sejam elas consideradas qualidades ou defeitos, em seu uso comum a pessoa pode vir a ser concebida como desprovida de "caráter". Ao tomar como referência esse sentido comum a campanha procura desnaturalizar a associação recorrente entre "falta de caráter" e "falta de religião". Veremos logo adiante, no entanto, que no plano das imagens essa dissociação se radicaliza, sugerindo até mesmo uma formulação inversa: é a presença mesma da religião que promove a falta de caráter.

É interessante notar que, se no nível da linguagem escrita as proposições são relativamente aceitáveis e podem ser lidas como divergências no plano das opiniões, quando acrescentadas às imagens as frases se revestem de escândalo, ainda que seus formuladores entendam que "nenhuma das peças exibidas é ofensiva". O efeito performático das imagens fecha o campo discursivo e transforma a arena do que se apresentava como um debate sobre opiniões em um sistema de acusações.

Os anúncios que tiveram maior repercussão e causaram a reação mais virulenta por parte dos religiosos foram os dois que mobilizam o imaginário do genocídio: a imagem do avião (islâmico) chocando-se com o World Trade Center e a que associa Hitler à religião.

O efeito retórico dessas imagens vai muito além do que está dito nas frases publicadas e chega até mesmo a contradizê-lo. No caso das Torres Gêmeas, os formuladores da campanha entenderam que essa imagem era a mais adequada para expressar "a insanidade que vem de um imperativo religioso". Essa escolha dispensou alternativas como "a tortura da Santa Inquisição" ou a "descrição das Cruzadas", que

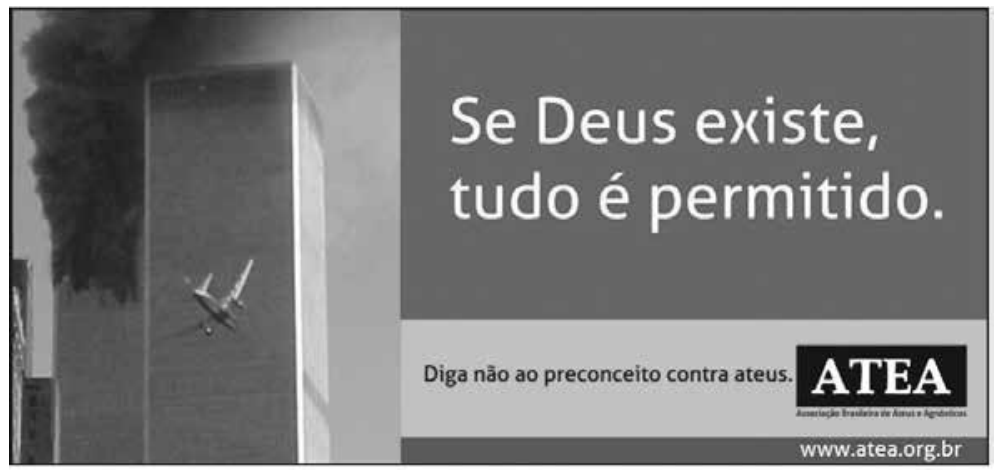




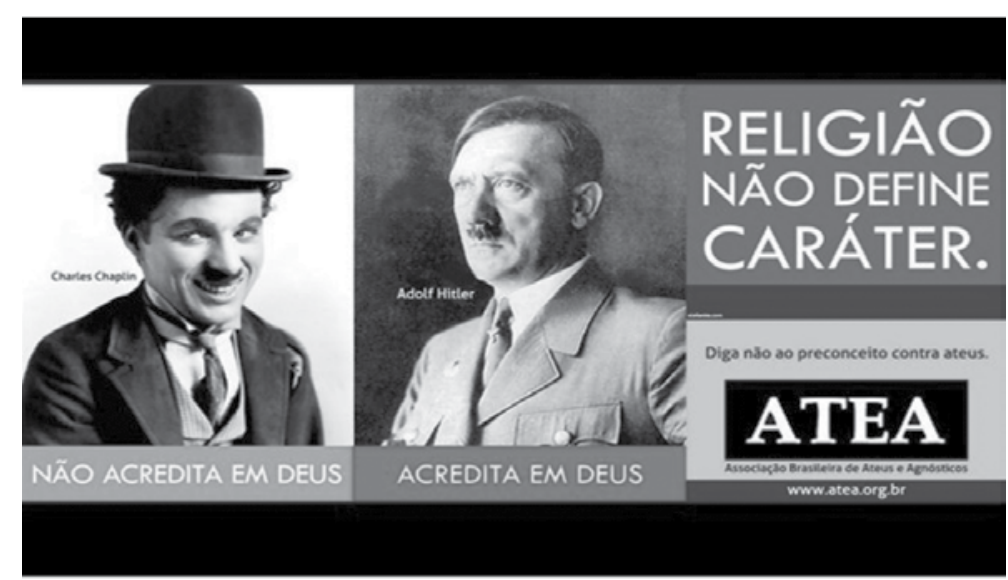

também apelam para o imaginário do genocídio, mas que não teriam ao seu dispor uma linguagem tão persuasiva como a da fotografia. $\mathrm{O}$ efeito verdade da fotografia desloca o debate abstrato sobre os fundamentos da moralidade para o campo dos fatos (i)morais efetivamente praticados. Nesse giro, reifica e imobiliza a representação do ser religioso na posição do insano, do terrorista, do genocida que comete crimes contra a humanidade. A associação da frase sobre o caráter com a imagem de Hitler evoca todos os compromissos históricos que a Igreja Católica estabeleceu com o nazifascismo europeu e com as ditaduras latino-americanas ${ }^{15}$. Em resposta, religiosos modificaram o original e colocaram no lugar da imagem cândida de Chaplin fotografias de Stalin, Che Guevara e outros personagens comunistas, como abaixo.

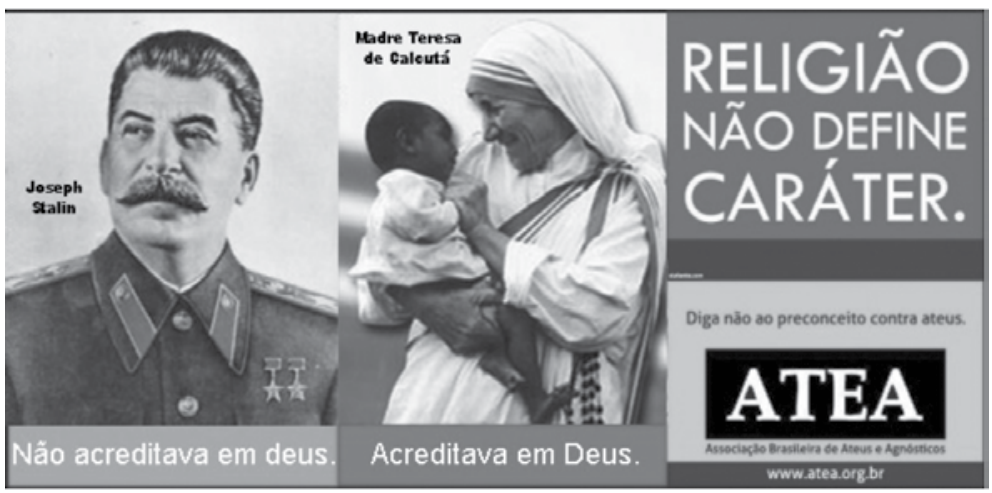

Nessa guerra de imagens, a controvérsia se desloca, portanto, da chave da moralidade individual e se generaliza, passando para o plano da crítica aos sistemas políticos e instituições. Nesse plano o debate, na verdade, desaparece. Tendo como pano de fundo o consenso em torno do genocídio como barbárie, os argumentos novamente aqui
[15] Vervídeo em http://oferrao.atarde.uol.com.br/?p=5772. Consultado em 26/4/2014. 
performatizam um sistema de acusações: para cada exemplo de genocídio perpetrado por sistemas políticos apoiados por sistemas religiosos acionado pela narrativa ateísta, outro exemplo de genocídio perpetrado por sistemas políticos não religiosos será evocado pela narrativa religiosa. É difícil avaliar o efeito dessa dramatização na construção da posição ateísta. No entanto, no contexto atual no qual "ser religioso" ou "ter religião" depende cada vez menos de uma identificação institucional, poderíamos afirmar que as críticas ao que fazem as igrejas não afetam necessariamente aquilo que as pessoas entendem por "religião".

A frase seguinte, "A fé não dá respostas. Só impede perguntas", vem acompanhada da imagem de duas mãos segurando uma Bíblia.

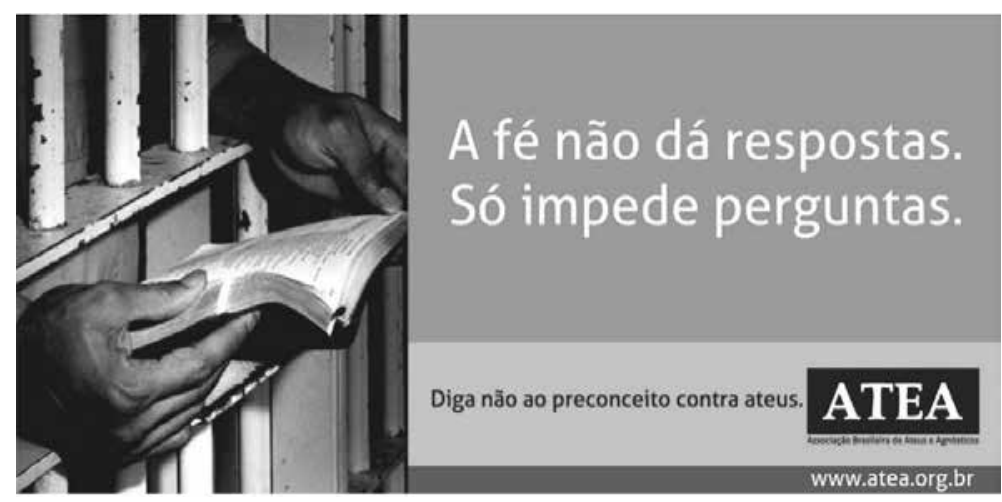

[16] http://www.atea.org.br/index. $\mathrm{php} /$ index.php?option $=$ com_content\&view $=$ article \&id $=222 \&$ Ite$\mathrm{mid}=118$. Consultado $\mathrm{em} 27 / 4 / 2014$.
O que poderia ser apenas a imagem comum de um fiel protestante torna-se intrigante pelo fato de as mãos estarem apoiadas nas grades de uma prisão. Ao contrário das duas mensagens anteriores, o ruído é introduzido não pela imagem, mas pela frase que a acompanha. O prisioneiro, que parece buscar a resposta para sua condição na Palavra, é desmentido: não é ali que ele encontrará a Verdade. Na perspectiva de seus idealizadores, a imagem sugere que "a (própria) fé é uma prisão" ${ }^{16}$. É interessante observar, no entanto, que essa imagem de mãos sobressaindo às grades de um cárcere em precaríssimas condições é bastante rotineira no imaginário brasileiro. A imagem de uma Bíblia nas mãos de um pobre sofredor se acomoda bem à ideia que se tem daquilo que um indivíduo poderia fazer para suportar semelhantes condições. Tendo em vista esse contexto, dificilmente a leitura dessa imagem levaria o público a considerar a Bíblia como a verdadeira prisão do sujeito, e não a prisão ela mesma. De qualquer modo, o hiato que caracteriza essa conjunção revela uma leitura que opõe fé e razão. Embora os formuladores da campanha afirmem que esse anúncio se opõe "ao preconceito que emana da fé", o efeito retórico que essa imagem 
põe em circulação é uma desqualificação culta do pensamento religioso como pouco razoável e alienante ${ }^{17}$.

Finalmente, a última frase, como a anterior, é mais contundente pelo que diz do que pela imagem que veicula.

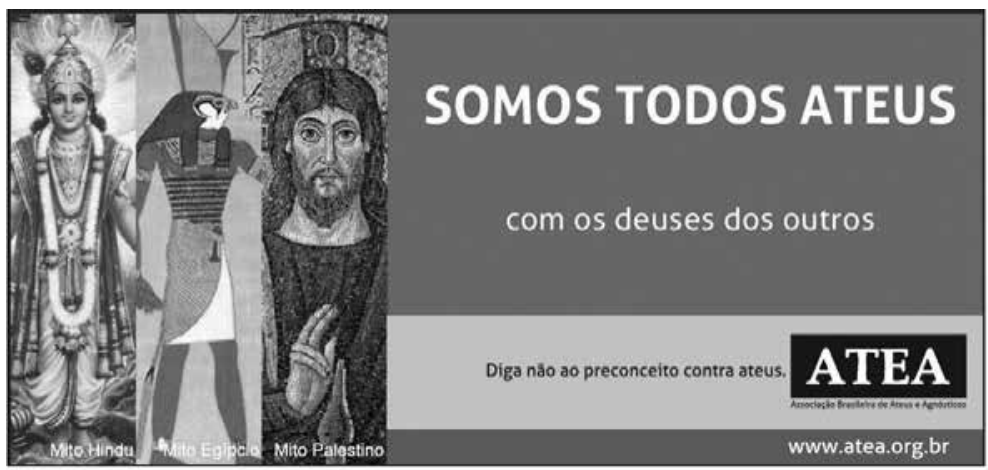

Quando se observam as imagens escolhidas, chama atenção que elas venham apodadas pela categoria "mito" e que a preferência para sua designação tenha sido seu lugar de origem e não o nome de uma divindade: "mito hindu" é a legenda para a figura de Vishnu, deus responsável pela manutenção do universo; "mito egípcio" para a figura de Hórus, considerado o iniciador da civilização egípcia; e "mito palestino" para a imagem de Jesus. Esse modo de representar divindades remete a um denso e ilustrado debate teológico/histórico/arqueológico em torno da historicidade dos textos bíblicos que já produziu imensa bibliografia. As imagens de Jesus e Hórus usadas na campanha circulam amplamente nas redes ateístas e de outros movimentos que reivindicam o uso de métodos científicos na leitura das religiões. Colocadas assim, lado a lado, aparecem no livro do teólogo Llogari Pujol e sua mulher, a historiadora Claude Carcenac, Jesus 3000 años antes de Cristo? Jesús y el Antiguo Egipto, editado pela Grijalbo em 2003. Comparando imagens bíblicas com as do Antigo Egito, os autores sugerem, nesse trabalho, que os evangelistas se inspiraram nos contos populares egípcios, que estavam então muito na moda na Palestina, para construir a vida de Jesus e a essência de seu personagem mítico. Embora não sejam os primeiros nem os únicos autores a fazer esse tipo de comparação, o livro circulou nas redes ateístas e provocou grande polêmica entre teístas e ateístas que, usando de grande erudição, procuravam, cada um a seu modo, demonstrar a veracidade ou falácia histórica das passagens bíblicas. A "crença" na verdade literal dos fatos bíblicos é um clichê recorrente nas acusações de "fundamentalismo" religioso por parte dos não religiosos. Evidentemente a remissão a esse amplo debate, que no Brasil permanece circunscrito a um pequeno número de aficionados, não é legível para o grande público. Lançando mão de
[17] Harding chama atenção para o pervasivo enquadramento modernista com o qual o pensamento cultivado representa of fundamentalismo como "retrógado", "literal", "intolerante", "inculto" etc. Harding, Susan. "Representing Fundamentalism: the problem of the repugnant cultural other". Social Research, vol. $58, \mathrm{n}^{\circ} 21,1991$. 
um repertório crítico bem conhecido nas redes e nos círculos ateístas contra uma leitura literal da Bíblia, a tentativa da campanha de transformar os deuses em personagens míticos construídos historicamente tende a permanecer demasiadamente criptográfica para realizar o efeito desejado. $\mathrm{Na}$ falta desse referente, tende a prevalecer uma leitura dessa sequência de "deuses" na chave da diversidade religiosa.

\section{AS REAÇÕES RECEBIDAS}

Foram três as grandes cidades em que a campanha foi recusada a partir de justificativas legais: São Paulo, Salvador e Porto Alegre. Somente em Florianópolis apresentou-se o argumento de que o conteúdo era "ofensivo". No caso de São Paulo, recorreu-se à legislação estadual que proíbe:

Capítulo 6, item 20:I a veiculação de mensagens publicitárias que infrinjam a legislação vigente, atentem contra a moral e os bons costumes, possuam temas de cunho religioso ou político partidário, que possam prejudicar o desenvolvimento operacional do sistema metroviário ou a imagem da CompanhiadoMetrôe ou que possam suscitar comportamentos inadequados.

Já no caso de Salvador a empresa contratada alegou que a campanha infringia a legislação municipal que proíbe anúncios que "favoreçam ou estimulem qualquer espécie de ofensa ou discriminação racial, sexual, social ou religiosa", ou quando for "considerado atentatório, em linguagem ou alegoria, à moral pública e aos bons costumes" (ênfases adicionadas). Assim, a campanha violaria o decreto municipal 12.642, de 28 de abril de 2000 . Finalmente, em Porto Alegre a Agência de Transporte Público alegou que a exibição das peças violaria o decreto municipal 11.460, de 1996, que estabelece em seu artigo ${ }^{\circ}$ :

$\S 2^{\circ}$ É vedada a veiculação de anúncios que estimulem algum tipo de discriminação social, racial, de credo, de atividade ilegal, de incentivo à violência ou que veicule propaganda de produtos que comprovadamente poluam ou façam mal à saúde e ao meio ambiente, bem como de cigarros, bebidas alcoólicas e motéis. (ênfase adicionada)

Assim, embora a campanha não se pense como religiosa, mas como não religiosa (ou até mesmo como antirreligiosa), a legislação na qual ela é enquadrada é a que diz respeito a qualquer afirmação ou imagem que pretenda fazer uso da religião em sentido amplo. Com isso, podemos dizer que ela entra no campo das disputas sobre o que é religião e que sua definição é sempre feita em relação ao que se compreende como religioso. Por outro lado, é possível argumentar que, ao se apre- 
sentarem essas legislações como justificativa, permanece uma ambiguidade ou até mesmo uma dupla condenação. Isso se deve ao fato de que o mesmo artigo regula a discriminação religiosa e a ofensa à moral e aos bons costumes. Vemos aqui como a dupla entrada das mensagens da ATEA (da crença/religião e da moralidade) está presente na própria legislação. Ao questionar simultaneamente essas duas dimensões e a sua relação, a campanha brasileira está disputando o sentido de moralidade estabelecido no campo religioso.

Além disso, ao afirmar que as imagens ferem moralmente os costumes socialmente estabelecidos, a justificativa jurídica apresentada pôde ser compreendida pela ATEA como uma continuação do preconceito contra aqueles que não creem, já que a divulgação da posição deles é uma ofensa a esses costumes hegemônicos. A partir dessa interpretação, a ATEA cogitou acionar juridicamente as companhias. Sua justificativa era que um Estado laico é um Estado que permite a livre expressão também daqueles que não creem.

Curiosamente, os mesmos artigos legais utilizados para recusar a campanha são por eles mobilizados para defendê-la. É interessante observar que, como no caso de muitos outros movimentos sociais, o "ativismo jurídico", ou a opção preferencial pela via legal,é a principal forma de ação política da ATEA. Isso se explica em parte porque, no entender de Sottomaior, as ações políticas intermediadas pelo Poder Legislativo ou pelo Poder Executivo são infrutíferas, pois frequentemente a pressão dos interesses políticos se sobrepõe ao cumprimento da legislação. A seu ver, apenas o Poder Judiciário é capaz de agir com isenção e fazer com que a discriminação seja percebida como tal.

Mas o ativismo jurídico da ATEA também se realiza em nome da laicidade do Estado. Sottomaior cita inúmeros casos nos quais esse princípio é negligenciado, tal como na inscrição "Deus seja louvado" nas notas de dinheiro, na presença de símbolos religiosos em locais públicos e nas tentativas de impor a oração do pai-nosso em escolas públicas. Em todos esses casos, o que se reivindica é uma defesa da laicidade do Estado e da liberdade de não crer. No entendimento de Sottomaior, a religião como objeto de escolha livre de uma consciência individual deveria permanecer restrita à dimensão privada. A laicidade, compreendida como uma "neutralidade, plena, completa e absoluta" do Estado, exigiria que este renunciasse a qualquer tipo de intervenção no campo religioso e na vida privada.

Porém, ele considera que apenas o movimento LGBT, em sua luta contra a presença religiosa na esfera pública e em cargos políticos, teria compreendido o "verdadeiro sentido da laicidade". Essa aproximação dos ateus com o movimento LGBT no entendimento da laicidade pode ser mais bem compreendida quando se considera que ambos se aliam na disputa contra as posições consideradas "conservadoras" 
[18] Link do arquivo de audio: http:// podcast.cancaonova.com/programa.php?id=2774. Consultado em 16/12/2010.

[19] Link do arquivo de audio: http:// podcast.cancaonova.com/programa.php?id=2769. Consultado em 16/12/2010. dos religiosos. No centro do debate estão a proibição do aborto e do casamento de pessoas do mesmo sexo e a pesquisa científica com células-tronco. No entanto, quando os ateus assumem essa aliança com as minorias sexuais, a questão da laicidade como neutralidade do Estado se complica. Como se sabe, o problema das minorias põe em ação a ideia de direitos positivos diante dos quais o Estado se engaja diretamente em uma política de tratamento diferenciado de uma coletividade particular.

Embora tenha movimentado as redes sociais mais diretamente interessadas no tema do ateísmo, a exibição dos outdoors em Porto Alegre não causou impacto na mídia brasileira e seu teor não alcançou o grande público. Os jornais mais importantes limitaram-se a dar pequenas notas informativas descrevendo a campanha e seus objetivos. Na maior parte das vezes não se estenderam em uma análise de fundo sobre a questão ateísta no Brasil; praticamente se restringiram à reprodução dos posicionamentos de Daniel Sottomaior a respeito do preconceito contra os ateus.

Pode-se, portanto, afirmar que, de um modo geral, a campanha suscitou controvérsia apenas nos meios intelectuais e religiosos associados ao catolicismo. Com efeito, é interessante notar o total silêncio de atores relacionados às outras instituições religiosas. À parte um ou outro editorialista, como o articulista do jornal Folha de S.Paulo Hélio Schwartsman, que defendeu claramente a campanha da ATEA, jornalistas, pesquisadores, juristas não expressaram nenhuma opinião a respeito do evento. Seria necessário, na verdade, empreender uma pesquisa mais ampla para compreendermos o sentido dessa abstenção. De todo modo, quaisquer que tenham sido as razões da pouca repercussão do movimento, pode-se verificar, no modo como a imprensa e os blogs trataram o assunto naquele momento, que o debate mobilizou apenas pessoas bem colocadas no establishment católico tais como o conhecido jurista católico e liderança do Opus Dei no Brasil Ives Gandra Martins ${ }^{18}$ e o cardeal arcebispo de São Paulo, dom Odilo Pedro Scherer ${ }^{19}$.

Em entrevista concedida ao site da Canção Nova em dezembro de 2010, Gandra Martins defende que a campanha brasileira viola a Constituição em seu artigo $3^{\circ}$ porque "além de mentirosa [...] discrimina aqueles que acreditam em Deus". O conteúdo das mensagens publicadas foi considerado por ele "agressivo e preconceituoso" porque não tem por objetivo apenas "defender o direito de ser ateu", mas sim "agredir a própria religião". Pode-se perceber nessa formulação que os dois lados do debate usam como referente comum o conceito político de "minoria" e constroem sua posição como vítimas de atos de discriminação perpetrados pelo oponente: uns por serem ateus, outros por terem religião. 
Dessa forma, pode-se concluir que o modo como as divergências são delineadas está constrangido pelos princípios da "liberdade de expressão" e da "tolerância à diferença", aceitos por ambas as partes como princípios legítimos do Estado de direito. "Uma verdadeira sociedade democrática não pode ter preconceitos, e essas campanhas são preconceituosas”, afirma Ives Gandra. Já para Sottomaior, em sua resposta a essa entrevista, "fazer os religiosos se sentirem atacados por ateus é uma estratégia eficaz para advogados da Cúria Romana. Com o medo, impede-se que indivíduos possam se aproximar das linhas do livre-pensamento" 20 .

Como já bem haviam observado Eliacheff e Larivière $^{21}$, há uma forte ligação entre democracia e vitimização. A compaixão pelas vítimas "tornou-se a primeira qualidade de um homem político, tanto da direita como da esquerda". Além disso, "os direitos acordados às vítimas têm por objeto ir no sentido da igualdade, e mais ainda, do pertencimento a uma humanidade comum". Assim, pode-se dizer que no debate entre Gandra e Sottomaior está em jogo a disputa pela posição da vítima. Para Gandra os ateus sempre foram reconhecidos como "cidadãos plenos e dignos", pelo menos por ele; já a campanha é preconceituosa porque pretende "desmoralizar os que acreditam". "Nada é tão ruim, num Estado democrático de direito, como a tentativa de impor um pensamento, principalmente pensamentos que são minoritários, discriminando aqueles que pensam de maneira diferente", conclui Gandra. Sottomaior procura inverter as posições afirmando que "nossa guerra é contra ideias, não contra pessoas".

Quando analisamos o debate no conjunto dos argumentos é possível perceber que, como já observamos acima, o terreno da disputa, embora assuma uma linguagem jurídica, não escapa propriamente do campo da disputa religiosa. Gandra afirma que os ateus são "profundamente religiosos na negação da existência de Deus, a sua religião éa negação de Deus". E, segundo ele, essa minoria fundamentalista estaria tentando impor sua opinião (leia-se crença) de maneira autoritária, desfigurando o pensamento da maioria que não pensa como eles. Sottomaior, de sua parte, afirma: "reconhecer o fundamentalismo como uma praga é dizer implicitamente que a religião só se torna aceitável quando não é levada lá muito a sério, ideia com que enfaticamente concordam centenas de milhões de 'católicos não praticantes' e religiosos que preferem se distanciar de todo tipo de igrejas e dogmas".É interessante como Sottomaior acaba por dar razão, nessa formulação, à acusação de intolerância feita por Gandra. Se a religião não deve ser levada a sério, não há como argumentar que se deva respeitá-la. Em sua "crítica às ideias religiosas" Sottomaior não consegue escapar à armadilha de sua própria posição duplamente religiosa: ou bem se instala no plano teológico e falsifica as "mentiras" propaladas pelas ideias [20]http://wwwl.folha.uol.com.br/ fsp/opiniao/13603-o-fundamentalismo-de-cada-dia.shtml.

[21] Larivière, Caroline Eliacheffe Solez, Daniel. Le Temps des victimes. Paris: Editions Albin Michel, 2007, p. 14. 
religiosas, ou bem se instala no campo da disputa religiosa e falsifica a "verdade" dos deuses alheios.

$\mathrm{Na}$ entrevista concedida no mesmo site do movimento católico carismático, Canção Nova, dom Odilo Scherer enfatizou a questão do artificialismo da campanha: "Eu primeiramente diria que se trata de uma questão posta artificialmente no Brasil, [que] está suscitando um problema que em si não existe", afirma ele. Poderíamos inicialmente nos perguntar qual seria, exatamente, o "problema inexistente" no Brasil sugerido pelo arcebispo. Pelo que se pode depreender na sequência de sua fala, o entrevistado está se referindo mais especificamente ao fato da ausência de "perseguição aos ateus" no Brasil: "Primeiramente, não existe uma situação de discriminação, de perseguição de ateus e agnósticos. Ateus e agnósticos sempre existiram, e existem também hoje, e de fato têm a liberdade de se expressarem, ninguém lhes tirou a liberdade de se expressarem", afirma o arcebispo. Em sua reação, o entrevistado recusa, pois, os próprios termos a partir dos quais a campanha foi formulada "diga não ao preconceito contra ateus" negando-lhe seu fundamento histórico, pelo menos no caso brasileiro:

[o] problema, propriamente não é sentido [aqui], isso [é] alguma coisa importada de algum lugar, de algum grupo de ativistas ateus lá na Europa, onde agente tem ouvido falar.

Esse modo de apresentar a situação revela uma dimensão interessante da invisibilidade do ateísmo no Brasil: ela não diz respeito apenas ao aspecto numérico dos ateus, mas, sobretudo, à ausência de uma percepção de conflituosidade que os torne objeto claro de alguma forma de perseguição e/ou agressão enquanto coletividade. Ao contrário dos movimentos homossexuais e antirracistas com os quais procura se aliar politicamente, o ateís mo é percebido como uma "escolha" individual e íntima, uma "convicção" a ser respeitada. E o princípio geral de respeito pelas diferentes convicções é aceito por todas as posições que se enfrentam nesse debate: "a única coisa é que é necessário o respeito também pelos outros, de maneira que a minha forma de expor o meu pensamento não seja uma agressão à posição do outro, e também, às convicções do outro", afirma o cardeal. Desse modo, ainda que "minoria" numérica, a fragilidade dos fatos a partir dos quais o ateísmo procura constituir-se como minoria socialmente perseguida torna sua causa, pelo menos até o momento, pouco convincente. O debate perde assim seu objeto, e a dimensão da arbitrariedade das acusações ateístas contra as religiões e de seu caráter ofensivo ganha mais verossimilhança. A campanha, que se apresenta como uma "luta política", é tomada pela outra parte 
como simples "provocação", incitamento ao conflito pelo conflito e, consequentemente, uma afronta que não merece resposta. "A melhor forma dos cristãos, das pessoas de fé, conviverem com isso, que de fato se apresenta como uma espécie de provocação, é se firmarem mais na própria fé", conclui o arcebispo. Nessas condições nas quais o objeto da luta política não se constitui legitimamente e a "fé" passa a ser a resposta a "provocações", o debate público se desqualifica e não tem possibilidade de instituir-se enquanto tal, permanecendo no campo das acusações mútuas restritas ao pequeno círculo dos que se sentem afrontados.

\section{CONSIDERAÇões Finais}

Ao lançar a campanha, a ATEA buscava posicionar-se publicamente como uma minoria política, afirmando que ser ateu faz da pessoa um alvo do preconceito. Porém, o resultado não esperado foi o seu reconhecimento como uma minoria religiosa, acusada de fundamentalismo e de ser tão intolerante e ofensiva quanto as posições religiosas que ela visava a combater. Para explicar esse aparente paradoxo, procuramos demonstrar que a posição social a partir da qual a associação pretendia se colocar publicamente não está disponível no contexto sócio-histórico do secularismo brasileiro atual, considerando três constrangimentos que devolvem o ateísmo para a posição religiosa. O primeiro é a presença ainda hegemônica da Igreja católica na vida pública e o importante papel que ela exerceu na formação da sociedade civil ao longo do século XX; o segundo é o modo particular como foi juridicamente formulado, no Brasil, o direito à liberdade religiosa; e o terceiro é a reivindicação por parte do movimento ateísta de uma posição de minoria que, de um modo geral, apenas se justificaria quando um destino social estigmatizante fosse coletivamente atribuído a um grupo, independentemente de suas escolhas conscientes. Esses dois últimos constrangimentos se tornam evidentes na análise quando se observa que tanto religiosos quanto ateus são levados a disputar suas posições com base na mesma linguagem jurídica e política, enfrentando-se, como em um jogo de espelhos, a partir de posições idênticas, mas invertidas. Retomemos, resumidamente, os três aspectos mencionados.

Conforme dissemos no início, o espaço civil brasileiro foi marcado por uma forte presença católica até os anos 1980. Desde então, houve uma diminuição progressiva da população que se declara católica e um aumento daqueles que se declaram cristãos não católicos. Houve, também, um significativo aumento daqueles que se declaram "sem religião". Porém, como vimos, "não ter religião" nãoé, necessariamente, sinônimo de ser "ateu". É preciso distinguir 
"sem religião" de "não religioso", pois o primeiro termo é usado para todos aqueles que, crendo, não possuem uma filiação institucional. Assim, o número de não religiosos pode ser apenas estimado, sem que exista uma clareza de sua proporção em relação às demais posições. Considerando a grande mobilidade religiosa, é possível que a maior parte dos $8 \%$ declarados sem religião seja de crentes em Deus. Outro aspecto desse constrangimento é a importância do catolicismo na formação da sociedade civil no Brasil. Principalmente do início da década de 1960 até o final dos anos 1980, a Igreja católica sustentou uma forte posição de esquerda e de oposição ao regime ditatorial imposto pelos militares. Com isso, foi uma das responsáveis pela organização de movimentos sociais, de lutas pela liberdade e pelos direitos humanos. A partir disso, ela posiciona-se como fomentadora da democracia num Estado laico. Além disso, sendo o declínio da hegemonia católica um fenômeno recente, a lógica social que confere plausibilidade à apresentação de si como uma "minoria" religiosa ainda não está plenamente estabelecida. Essas dificuldades reverberam nas tentativas da ATEA de se posicionar como uma minoria política, tornando-a pouco plausível.

Na medida em que a campanha buscava contrapor-seà religião nos dois eixos delimitados acima em nossa análise, por um lado, no da crença, por outro lado, no da moralidade, ela foi levada a inserir-se no campo de disputas delimitado pela própria religião católica e legitimado enquanto tal pelo Estado. Nesse caso, cabe ressaltar que o entendimento jurídico que dá suporte à laicidade do Estado brasileiro protege a liberdade religiosa e sustenta que as religiões não devem ser alvo de ofensas. Ora, a opção por não crer é, também, defendida pela mesma lei e, assim, acaba por encapsular a posição dos ateus como uma variante da liberdade religiosa.

Vimos que, nas legislações estaduais apresentadas como justificativas para negar a veiculação da campanha, são os mesmos artigos que impedem a discriminação racial, sexual e religiosa e defendem a moralidade e os "bons costumes". A tentativa de afirmar-se uma minoria política, espelhando-se nos movimentos negros e homossexuais, não encontra, pois, respaldo legal, estimulando a leitura da posição minoritária dos ateus na chave religiosa. Não crer na existência de Deus é percebido como uma escolha dentro do campo de possibilidades religiosas. Desse modo, a posição pretendida pelos ateus, de poder expressar publicamente suas críticas à religião situando-se ao mesmo tempo fora do campo religioso, não é uma posição historicamente possível no atual contexto social e jurídico brasileiro. Essa impossibilidade histórico/jurídica é reforçada pelo fato de que "ser ateu" é percebido como uma "escolha religiosa" individual tornada possível pela proteção legal, e não uma herança "natural” como a cor da pele ou 
a orientação sexual. O entendimento comum de que as pessoas são livres para escolher a própria "crença", um dos princípios mais bem-aceitos do Estado laico, é continuamente mobilizado aqui para definir o "ateísmo" como uma variante "religiosa".

Por fim, a própria estratégia política da ATEA acaba por reforçar essa leitura "religiosa" de sua atuação. Nosso argumento aqui sugere a existência de um espelhamento entre ateus e religiosos nas formas de se posicionar e agir publicamente. Esse espelhamento se torna visível em dois planos: na formulação da campanha e nas respostas jurídicas e sociais.

Ao formular a campanha, um dos objetivos declarados de seus idealizadores era relativizar a crença. Para isso, afirmaram que "somos todos ateus, com os deuses dos outros". Porém, essa afirmação aceita o suposto latente da existência de um Deus, ao menos aquele que é verdadeiro para um sujeito. Some-se a isso a imagem da religião como fonte de malefícios e tragédias, como o avião colidindo com as torres do WTC e a Bíblia na mão de um presidiário. Essas imagens recolocam o debate no campo da disputa doutrinária intrarreligiosa, ao indicar que eles são descrentes apenas com relação às crenças dos demais, mas que possuem uma crença mais verdadeira. Esses dizeres os posicionam, portanto, como uma crença alternativa com relação à crença dos outros. A análise dos slogans e imagens da campanha demonstrou que a proposta da ATEA disputou, certamente em desigualdade de posições, dois campos de debate nos quais as religiões já têm longa experiência e farta reflexão: o estatuto da crença e a religião como fonte de moralidade.

No que tange às respostas jurídicas, pode-se observar o uso de uma mesma linguagem, jurídica e política, entre o presidente da ATEA e o jurista Ives Gandra. Ambos aceitam os termos do debate: a liberdade religiosa, a noção de minoria e a existência de vítimas, mas competem entre si para ser publicamente reconhecidos como os verdadeiros ofendidos e se acusam mutuamente de fundamentalistas. Para Sottomaior, são os ateus que sofrem preconceito por não acreditarem em Deus, sendo alvo do fundamentalismo religioso. Eles teriam o mesmo estatuto das minorias políticas, como negros e homossexuais. Para Gandra, eles são os ofensores, fomentando a intolerância religiosa e pondo em risco a paz social. Tentariam, ainda, impor a toda a sociedade uma visão pouco representativa o que lhes confere características autoritárias e contrárias ao regime democrático.

Para além dos constrangimentos políticos e jurídicos que deram à campanha um sentido não previsto pelos seus idealizadores, gostaríamos de sugerir que a escassa visibilidade da campanha está também relacionada à pouca densidade e sofisticação científica, in- 
[22] https://www.youtube.com/watch?v=OrTYmOSgYzY. telectual e mediática desse debate no Brasil. Com efeito, observando o debate sobre o ateísmo no plano mundial, pode-se perceber que as proposições defendidas remetem continuamente a um vasto campo de conhecimento e erudição acumulados ao longo de várias décadas de reflexão, ensino e debate público entre intelectuais de prestígio tanto no campo das ciências quanto no campo das religiões. No caso brasileiro, o limitado acesso da população à universidade, a relativamente mal distribuída cultura científica e a total ausência de estudos religiosos como disciplina acadêmica instituída nas universidades públicas são alguns dos condicionantes históricos que restringem as possibilidades de alargamento desse debate para o conjunto mais amplo das camadas cultas, mantendo-o confinado ao pequeno círculo dos mais diretamente interessados pelo problema. À falta de um repertório científico, filosófico, literário e teológico relativamente vasto, os atores envolvidos como a ATEA acabam por privilegiar o campo político da discriminação contra as minorias como arena principal do debate.

Embora a campanha de Sottomaior tenha se inspirado em questões presentes no debate internacional, o problema do ateísmo como minoria e como ofensa ganhou no caso brasileiro configurações muito particulares. Se tomarmos como exemplo o vídeo, de grande circulação, Os quatro cavaleiros do ateísmo ${ }^{22}$, que coloca em cena uma troca de opiniões entre quatro conhecidos intelectuais ateus, Christopher Hitchens, jornalista e crítico literário inglês, Richard Dawkins, biólogo e escritor também britânico, Sam Harris, filósofo e neurocentista americano, e Daniel Dennet, filósofo e um dos mais conhecidos ateus americanos, veremos que apresentar-se como minoria é, para esses pensadores, cometer o mesmo erro dos religiosos que tomam a crítica como ofensa pessoal. Isso porque, para eles, o ateísmo é uma atitude intelectual que tem por objeto a crítica das ideias religiosas, e não uma "crença a ser protegida". Consideram ter o direito legítimo de discordar das ideias religiosas e criticá-las publicamente sem que isso seja necessariamente tomado como insulto ou desqualificação. Esse posicionamento nos leva ao delicado problema da ofensa. Um dos interlocutores do vídeo acima mencionado, Daniel Dennett, observa como é difícil debater nesse campo sem que a ofensa surja como elemento desse jogo. Para ele, os religiosos usam do artifício dos "sentimentos feridos" para tornar impossível a discordância. Tomando como referência o campo do debate científico, no qual a falsificação de uma teoria não é lida como uma ofensa pessoal, seu colega Sam Harris conclui que é impossível argumentar em um debate com os religiosos: eles são capazes de demonstrar a implausibilidade das crenças alheias, mas não são capazes de usar argumentos para defender a sua própria opinião. 
No caso brasileiro, ao contrário, o problema da ofensa não tomou como referência o ethos científico da falsificação dos argumentos, mas sim o ethos político/moral do "reconhecimento" da diferença. Em razão da ausência de personagens acadêmicos publicamente reconhecidos nesse debate, o modus operandi da argumentação científica não funcionou como balizamento. Nesse sentido, o ateís mo brasileiro não tinha como dispor do capital cultural necessário para apresentar-se como uma "atitude intelectual de questionamento da fragilidade dos argumentos religiosos". $\mathrm{Na}$ falta dessa possibilidade, o debate deslocou-se para o campo da crítica política ao autoritarismo: independentemente de sua razoabilidade, as ideias não podem ser nem perseguidas, nem impostas. Nesse sentido, toda oposição à crítica das ideias religiosas, que no caso do debate anglo-americano foi libelada como fundamentalismo, será tomada no debate brasileiro como forma de autoritarismo. Parece não haver, tal como a crítica à posição ateísta foi formulada nas reações católicas à campanha, a possibilidade de um mundo no qual a religião seria erradicada por falsa sem que o imaginário político das ditaduras do mundo comunista fosse acionado. Essaé, no entanto, uma imagem bastante datada. É possível imaginar, e as novas gerações já começam a fazê-lo, inúmeras outras maneiras de viver sem religião.

\section{REFERÊNCIAS BIBLIOGRÁFICAS}

Almeida, Ronaldo de e Montero, Paula. "Trânsito religioso no Brasil”. São Paulo em Perspectiva, vol. 15, n $3,2001$.

Decol, René D. "Mudanças religiosas no Brasil: uma visão demográfica. Revista Brasileira de Estudos Populacionais, vol. 1/2, nº 16, 1999.

Dullo, Carlos Eduardo Valente.A produção de subjetividades democráticas e a formação do secularno Brasil a partir da pedagogia de Paulo Freire. Tese de doutoramento. Rio de Janeiro: UFRJ, 2013.

Harding, Susan. Representing Fundamentalism: the problem of the repugnant cultural other. Social Research, vol. 58, n² 2, 1991.

Larivière, Caroline Eliacheff e Solez, Daniel. Le Temps des victimes. Paris: Editions Albin Michel, 2007.

Montero, Paula. "O campo religioso, secularismo e a esfera pública no Brasil”. Boletim CEDES, PUC-RJ, 2011.

. "Secularização e espaço público: a reinvenção do pluralismo religioso no Brasil". Etnográfica, vol. 13, nº 1, 2009.

Monteiro, Adriana Carneiro; Barreto, Gley Porto; Oliveira, Isabela Lima de; Antebi, Smadar. 2010. Minorias étnicas, linguísticas e religiosas. s.1.: DHnet-Direitos Humanos, 2010. dhnet.org.br/dados/ cursos/dh/br/pb/dhparaiba/5/minorias.html. 
Recebido para publicação

em 19 de novembro de 2014.

\section{NOVOS ESTUDOS}

CEBRAP

100 , novembro 2014

pp. $57-79$
Oliveira, Pedro A.R. de. "Religiosidade popular na América Latina". Revista Eclesiástica Brasileira, fasc. 126, n 32, 1972.

Oliveira, Thales de. "Catolicismo no Brasil?" Revista Vozes, ano 63, n 2, fevereiro 1969.

Sanchis, Pierre. "As tramas sincréticas da história". Revista Brasileira de Ciências Sociais, vol. 28, 1995.

Souza, Ricardo Luiz de. "O anticlericalismo na cultura brasileira". Revista de Ciências Humanas. Florianópolis, n³7, 2005.

PAULA MONTERO é professora titular no departamento de Antropologia da Universidade de São Paulo e pesquisadora do Cebrap.

EDUARDo Dullo é pós-doutorando no Departamento de Antropologia da USP e pesquisador associado do Cebrap. 